\title{
The Victory of the Justice and Development Party in Turkey
}

\section{Metin Heper}

To cite this article: Metin Heper (2003) The Victory of the Justice and Development Party in Turkey, Mediterranean Politics, 8:1, 127-134, DOI: 10.1080/13629390308010006

To link to this article: https://doi.org/10.1080/13629390308010006

册 Published online: 08 Dec 2010.

Submit your article to this journal ๔

Џ Article views: 232

Citing articles: 4 View citing articles 5 


\title{
The Victory of the Justice and Development Party in Turkey
}

\author{
METİN HEPER
}

The November 2002 general elections opened a new page in Turkish politics. The members of the then coalition government - the Democratic Left Party (Demokratik Sol Parti; DSP), the Nationalist Action Party (Milliyetçi Hareket Partisi; MHP) and the liberal Motherland Party (Anavatan Partisi; ANAP) - as well as the main opposition party, the secular centre-right True Path Party (Dogru Yol Partisi; DYP), failed to attract sufficient votes to pass the electoral threshold of 10 per cent. Only two parties were able to return members to Parliament - the religiously oriented Justice and Development Party (Adalet ve Kalkınma Partisi; AKP), with 34.3 per cent of the votes and 363 seats, and the secularly oriented Republican People's Party (Cumhuriyet Halk Partisi; CHP), with 19.4 per cent of the votes and 178 seats. In addition, nine independents, with a total vote of 1.0 per cent, had been elected. In the event, 490 out of 550 members of parliament turned out to be new faces. ${ }^{1}$

The outgoing government had been the most harmonious coalition since 1961, the date when Turkey first started to be ruled by coalition governments. ${ }^{2}$ Furthermore, particularly the leaders of the DSP and MHP, Bülent Ecevit and Devlet Bahçeli, acted as responsible politicians. Consequently, their government was able to take courageous decisions regarding the economy, which they had found in a shambles and which furthermore was hit by two economic crises in November 2000 and February 2001. They thus prepared the path for an economic recovery, the first signs of which became visible in early 2003. The government also worked hard towards a commitment by the European Union (EU) to set a date for the opening of membership negotiations with Turkey. The leader of ANAP, Mesut Y1lmaz, played a particularly active role in these efforts.

Metin Heper is based at Bilkent University, Ankara.

Mediterranean Politics, Vol.8, No.1 (Spring 2003), pp.127-134

PUBLISHED BY FRANK CASS, LONDON 
Yet, the economic hardship that people faced in the wake of the two economic crises, as well as the widespread belief that some members of government, in particular those of ANAP, were involved in several corruption cases brought the demise of the government. It had failed to persuade people that the favourable trickle-down effects of its structural reforms in the economy would take time to be felt by large numbers of people. To make things worse, the media had relentlessly attacked the government for ineffectively handling the economy. ${ }^{3}$ The wrangling between Bahçeli and Yilmaz too did not help improve the fortunes of the coalition. Another development that adversely affected the future of the coalition was prime minister Ecevit's health problems that often incapacitated him for several days before the elections.

Thus, while in the April 1999 general elections the DSP, MHP and ANAP had garnered 22.1, 17.9 and 13.2 per cent of the votes, respectively, these figures dropped to 1.2, 8.3 and 5.1 per cent in November 2002. The particularly sharp drop in the DSP vote may be attributed not only to Ecevit's health problems, but also to the fact that on the eve of the elections Ecevit had indicated that he was toying with the idea of resigning from the DSP in the next few months. Since Mr and Mrs Ecevit had always almost single-handedly led the DSP, ${ }^{4}$ the voters might have thought that in the foreseeable future the DSP was destined to become a ship without a captain and, therefore, sink.

As soon as the results of the elections became apparent on election night, Bahçeli announced that he was going to resign from the MHP leadership. Many applauded this decision, because no unsuccessful leader in Turkey had by his/her own volition decided to step down for a long time. ${ }^{5}$ Following widespread requests from the MHP supporters to stay on, he did not resign, but kept a very low profile. Bahçeli's offer to resign was followed by a similar announcement by Y1lmaz. In his case, however, there were no pleas that he should remain at the helm of ANAP. On the contrary, the leading cadres of the party made statements aimed at discouraging Yilmaz from harbouring any such hopes. Y1lmaz eventually not only resigned from the leadership of his party, but also quit ANAP and politics in general.

The fact that not only all government parties but also the main opposition party failed to return to Parliament may come as a surprise to those who do not regularly follow political developments in Turkey. However, one can argue that the leader of the DYP, Tansu Çiller, was solely responsible for the failure of her party at the elections. Çiller had served as Turkey's first female prime minister from June 1993 until February 1996 in three successive coalition governments. In June 1996, Çiller did not see any problems in her becoming deputy prime minister in the coalition 
government that the DYP formed with Necmettin Erbakan's Welfare Party (Refah Partisi; RP), which she had previously criticized harshly. This was not the first time that Çiller had acted contrary to her previous claims. Furthermore, Parliament accused her of various misdemeanours during her tenure as prime minister. As a consequence, the support for Çiller has steadily declined. She had become the leader of the DYP in November 1990. In the December 1991 general elections the DYP received 27.0 per cent of the votes, in 199519.2 per cent, in 199912.0 per cent and in 2002 only 9.5 per cent. Çiller eventually resigned under pressure from her own party and from public opinion, but immediately, albeit unsuccessfully, she began manoeuvring to make a come-back. Her story is one of coming to power with a great fanfare, including great enthusiasm on the part of many in Turkey and abroad for the relatively young female professor in a predominantly Muslim country, and then having to make an exit from the political scene in a rather disgraceful manner. ${ }^{6}$

As Turkey went to elections in the first week of November 2002, it was expected that the AKP and CHP would easily surpass the ten per cent electoral threshold; it was also predicted that probably the DYP and, with less probability, the MHP could do the same. Yet the secularist pundits were proven wrong. Contrary to their expectations, for instance, the CHP trailed far behind the AKP in the elections. One reason why the party did not do as well as expected was that the leader of the party, Deniz Baykal, was suspect in the eyes of many for his factionalist politics. There were strong indications that some of those who thought the best strategy would be that of voting for the CHP were nevertheless unwilling to do so because they did not trust Baykal. Secondly, a substantial number of those who in the past had not voted for a religiously-oriented political party voted for the AKP this time. ${ }^{7}$ In previous general elections the votes of the religiously oriented parties stood at 11.8 per cent in 1973 (National Salvation Party), 8.6 per cent in 1977 (National Salvation Party), 7.2 per cent in 1987 (Welfare Party), 16.8 per cent in 1991 (Welfare Party in electoral alliance with Nationalist Workers Party and Reformist Party), 21.4 per cent in 1995 (Welfare Party) and 15.4 per cent in 1999 (Virtue Party - Fazilet Partisi; FP). In contrast, as noted, in the 2002 general elections the AKP's votes went up to 34.2 per cent (while the votes of the rival religiously oriented party - Felicity Party (Saadet Partisi) - remained at 2.5 per cent). ${ }^{8}$

The above figures indicate that since the 1970 s there has been a fluctuation rather than a steady increase in the votes of the religiously oriented parties in Turkey. How can one explain this particular voting record of the religiously oriented parties in that country? The space does not allow me an extended elaboration of this matter. Suffice it to point out that the Turkish Revolution of the 1920s was a cultural revolution that aimed at 
substituting a rational thinking pattern based on one's reasoning faculty for the practice of turning to Islam whenever one had to make a decision. ${ }^{9}$ The secularist reforms undertaken to realize this particular goal of the Revolution came to have a deep impact on the people. For the bulk of the people Islam virtually became a personal link with Allah, consisting of a system of personal belief-cum-ethics. For a few it also provided a road map for interpersonal relations. ${ }^{10}$ Those who continued to yearn for a state based on Islam constituted a very small percentage of the populace. A nationwide survey conducted in the early 1980s found that only seven per cent of the people in Turkey thought that the country should be ruled according to shariah. ${ }^{11}$ It should also be noted here that those who favour shariah rule in Turkey do not necessarily think it should be applied verbatim in all relevant cases. According to a 1999 nationwide survey, only one per cent of the respondents considered that those who commit adultery should be punished 'according to the Koran'. ${ }^{12}$ It seems that in Turkey the bulk of those in favour of shariah rule take it simply to be a form of good government.

It was under these circumstances that religiously-oriented political parties started to be formed in Turkey. The first such party, the National Order Party (Milli Nizam Partisi; MNP), established in January 1969, subscribed to the idea that Islamic order was incompatible with a secular order. As was expected, the Constitutional Court banned the party the next year on the grounds that its programme violated the constitutional norm that the Turkish state is a secular state. In the following decades the religiously oriented parties showed increasing signs of turning into pro-system parties. By the time the Virtue Party was set up in November 1997, the earlier discourse had turned into one affirming the separation of state and Islam.

The Virtue Party and its predecessor, the Welfare Party, were banned by the Constitutional Court; however, both parties were closed down not because of a clash between their programmes and the relevant provisions in the Constitution but because of provocative yet isolated statements made by marginal members of these parties. It is possible to argue that the religiously oriented parties in Turkey could by themselves garner votes as high as 16 per cent from a predominantly secular electorate. One may suggest that the fluctuations in their votes were not an outcome of the different degrees of religiosity these parties displayed, but rather an upshot of the extent of success they achieved in delivering goods and services to the people while in office. In fact, one study carried out in 1994 showed that two-thirds of those voting for the Welfare Party had done so because they thought a religiously-oriented party would be honest and would care for the people. Only one-sixths of the remaining third were for what is often called 'theodemocracy' - trying to capture government by democratic means in order to set up a state based on Islam. ${ }^{13}$ 
Since its inception the AKP has displayed stronger pro-system features than its predecessors. Between November 1997 and February 1998, its leader Recep Tayyip Erdoğan was the leader of the Innovators Group (versus the Orthodox Group) in the Virtue Party. Throughout his life, Erdoğan has had an inclination towards Sufi Islam, and therefore no tendency towards the idea of a state based on Islam. Erdoğan, in fact, thinks that true believers of all religions would have humanitarian concerns and, therefore, they all should be accorded respect. When he was the metropolitan mayor of Istanbul (1994-98), he set aside funds for the restoration of churches and synagogues, an achievement that had not been accomplished earlier by the secularly oriented metropolitan mayors of that city. Under directions from Erdoğan, the AKP has not only essentially kept its distance from political Islam, but has avoided even Islamic terminology and dress. ${ }^{14}$

Following the November 2002 elections, Erdoğan initially could not become prime minister because, after a controversial trial, he had been banned from active politics and, thus, could not run for Parliament in the elections. Following an amendment to the relevant legal provisions, he was finally elected prime minister in March 2003. In the meantime, another former leading member of the Innovators Group within the Virtue Party, Abdullah Gül, took the post on a caretaker basis. In his capacity as the leader of the AKP, Erdoğan visited several EU countries as well as the United States to push for a definitive date for Turkey from the EU at the Copenhagen Council for the start of accession negotiations.

Meanwhile, the AKP government on the whole continued to pursue the IMF-suggested austerity programme in order to pull Turkey out of its economic difficulties. Concerning the Cyprus issue, the government continuously urged the president of the Turkish Republic of Northern Cyprus, Rauf Denktaș, to make greater efforts for the resolution of the conflict, which has been singled out by the EU as one of the conditions for a start of negotiations in early 2005. As for the Iraqi crisis, the government made intensive efforts in support of solving the conflict by peaceful means, calling on Saddam Hussein to fully comply with UN Security Council resolution 1441, both unilaterally and in concert with moderate Arab countries.

The government also tried to co-operate with the United States, Turkey's strategic ally since the end of the Second World War, in the latter's efforts to neutralize Saddam Hussein. It honoured the US request and obtained from Parliament the enabling legislation to allow the United States to help modernize certain ports and airfields in Turkey for their possible use by US military in the event of war. However, the second US request to allow transit passage of about 40,000 US troops on their way to Iraq and the deployment 
of around 20,000 US troops in southeastern Turkey, while cautiously supported by the government on certain conditions, met with resistance by the bulk of public opinion, the CHP, President Ahmet Necdet Sezer as well as some members of the AKP parliamentary group, including some members of the government itself. In Parliament, 264 members voted 'Yes', 250 voted 'No' and 19 abstained. As the vote was three short of the absolute majority of those present, the government's bill was not accepted. The members of the CHP opposition party and 71 members of the AKP had voted against the bill.

Several factors seemed to have played a role in Parliament's decision. The most important reason was that the AKP leadership had not chosen to obtain a binding decision in the AKP parliamentary group before the vote on the bill. Gül and Erdoğan must have thought that they could persuade a great majority of AKP MPs to support the bill. In the event they could not. Some of those not persuaded might have been influenced by the results of polls indicating that close to 80 to 90 per cent of the people in Turkey were against the war. Some AKP MPs might have acted out of their nationalistic instincts. In Turkey nationalism and Islamism are to a great extent intermingled; even secularists continue to perceive Turkish identity (most of the time unconsciously) as not being entirely separate from being a Muslim. Some among the latter might have acted as pure ethnic nationalists as there are Kurdish-Turks among the AKP MPs. Still other AKP MPs may have had a Third Worldist approach to the issue. They might have been disturbed by 'the United States always taking Turkey for granted'.

In recent months, the way in which the US administation had given certain deadlines to Turkey and the condescending attitude of the American media towards Turkey, which included portraying the country as trying to use the crisis to strike a good bargain and nothing else, must have reinforced this resentment. There was also the fact that the speaker of the Parliament, Bülent Arınç, opposed the bill. In terms of prestige and influence within the AKP, he comes third after Erdoğan and Gül. ${ }^{15}$ Finally, the members of another, probably residual, group in the party must have cast their votes against the bill because of their opposition to 'one Muslim country taking a hostile attitude against another'.

For his part, Erdoğan warned everybody that such issues as the Iraqi crisis should not be used to serve narrow political interests. This statement was taken as an indication that the AKP was toying with the idea of introducing a second bill. It was at this juncture that the chief of the General Staff, Hilmi Özkök, made an important statement. He pointed out that from a humanitarian viewpoint everybody in Turkey, including the military, was against a war in Iraq. Yet, he argued, there would be a war, and that Turkey by itself could not prevent it from taking place. The choice Turkey faced 
was not one between 'good and bad, but between bad and worse'. Özkök then focused on the possibility of the establishment of an autonomous or even sovereign Kurdish political entity, and insisted that the Kurdish leaders in northern Iraq should remember that Turks and Kurds are friends, good neighbours and even relatives, before reminding them that Turkey had a right of self-defence and would not hesitate to exercise that right if necessary.

As should be apparent from the foregoing account, during their deliberations on such foreign policy issues as the EU, Cyprus and Iraq, AKP leaders have not drawn upon Islam in order to justify their views and policies. On the whole, AKP leaders have adopted a similar stance towards domestic issues. They openly stated that they would not interfere with the lifestyles of the people, and the headscarf issue (whether female students should be able to attend classes at universities with their hair covered), for instance, does not have priority on their agenda. From a secularist perspective, one adverse development here is the recent decision of the minister of education to start to appoint to that ministry the graduates of the Preachers and Prayer Leaders (high) Schools.

The present Turkish experiment of a religiously-oriented government in a predominantly Muslim country may disprove Samuel P. Huntington's 'clash of of civilizations' hypothesis. In any case, in Turkey one has not come across what Emmanuel Sivan recently reported as the characteristics of the clash between extremist Islamic elements and governments: economic downturns resulting in Islamic radicalism; Islamic radicalism becoming a major avenue for venting protest; the imposition of Islamic dress codes and monitoring the behaviour of non-Islamic tourists; subjects relinquishing their claims to basic human and civil rights in return for the state providing goods and services; some associations tending to take a stand in favour of the application of the shariah; the osmosis of radical Islamic ideas into the conservative Islamic establishment; the institutional ulama controlling religious education in the state system; or the soft conservative-liberal centre embracing authoritarian regimes for fear of alternatives. ${ }^{16}$ Since its foundation in 1923, Turkey has made significant progress towards a reconciliation of its Islam with modernity as well as democracy.

\section{NOTES}

1. On political party dynamics in Turkey, see Metin Heper and Jacob Landau (eds.), Political Parties and Democracy in Turkey, London: I.B. Tauris, 1991; Barry Rubin and Metin Heper (eds.), Political Parties in Turkey, London and Portland, OR: Frank Cass, 2002.

2. On Turkey's experience with coalition governments in the 1961-99 period, see Metin Heper 
and Filiz Bașak, 'The Politics of Coalition Government in Turkey, 1961-1999: Toward a Paradigmatic Change?', International Journal of Turkish Studies 7 (2001): 68-89.

3. On the media in Turkey, see, inter alia, Șahin Alpay, 'Journalists: Cautious Democrats', in Metin Heper, Ayșe Öncü and Heinz Kramer (eds.), Turkey and the West: Changing Political and Cultural Identities (London: I.B. Tauris, 1993).

4. Suat Kınıklığlu, 'The Democratic Left Party: Kapıkulu Politics [Politics of Obedience]', in Rubin and Heper (eds.), Political Parties in Turkey.

5. On the dominant roles political party leaders in Turkey have in their parties, see Metin Heper and Sabri Sayarı (eds.), Political Leaders and Democracy in Turkey, Boulder, CO: Lexington Books, 2002.

6. On Tansu Çiller, see Ümit Cizre, 'Çiller: Lusting for Power and Undermining Democracy', ibid.

7. On the secularist versus Islamist conflict in Turkey, see Nilüfer Göle, 'Authoritarian Secularism and Islamist Politics: The Case of Turkey', in Augustus R. Norton (ed.), Civil Society in the Middle East (Leiden: E.J. Brill, 1996); Mustafa Erdoğan, 'Islam in Turkish Politics: Quest for Democracy without Islam', Critique 15 (1999), pp.25-50; and Metin Heper, 'Islam and Democracy in Turkey: Toward a Reconciliation?' Middle East Journal 51 (1997), pp.32-45.

8. The Virtue Party was banned in May 1999 by the Constitutional Court. The Felicity Party and Justice and Development Party emerged as the two successor parties.

9. Șerif Mardin, 'Ideology and Religion in the Turkish Revolution', International Journal of Turkish Revolution 2 (1971), pp.197-211.

10. Howard Reed, 'Revival of Islam in Secular Turkey', Middle East Journal 8 (1954), pp.33-44; Bernard Lewis, 'Why Turkey is the Only Muslim Country with Democracy', Middle East Quarterly 1/1 (1994), pp.41-49; Metin Heper, 'Islam, Polity and Society in Turkey: A Middle Eastern Perspective', Middle East Journal 35 (1981), pp.345-63; and idem, 'The State, Region and Pluralism: the Turkish Case in Comparative Perspective', British Journal of Middle Eastern Studies 18 (1991), pp.38-55.

11. İlter Turan, 'Religion and Political Culture in Turkey', in Richard Tapper (ed.), Islam in Modern Turkey: Religion, Politics, and Literature in a Secular State, London: I.B. Tauris, 1991, p.55.

12. Reported in Milliyet (Istanbul daily), 9 April 1999.

13. Reported in Nokta (Istanbul weekly), 26 June-2 July 1994.

14. On Erdoğan, see Metin Heper and Şule Toktaş, 'Islam, Modernity, and Democracy in Turkey: The Case of Recep Tayyip Erdoğan', Muslim World 93/2 (April 2003), pp.157-85.

15. Arınç seems to have taken offence at the fact that he was passed over for the position of (caretaker) prime minister while Gül was appointed.

16. Emmanuel Sivan, 'The Clash within Islam', Survival 45/1 (2003), pp.25-44. 